\title{
Perspectives
}

\section{A World South-Side Up?}

\section{Global Health and the Provincializing of Europe}

\author{
Frank Huisman \\ Full Professor; Department of Public Health, Healthcare Innovation \& \\ Evaluation and Medical Humanities (PHM), University Medical Center, \\ Universiteitsweg 100, 3584 Utrecht, The Netherlands \\ f.g.huisman-3@umcutrecht.nl \\ Nancy Tomes \\ Distinguished Professor; Department of History, Stony Brook University, \\ Stony Brook, NY 11794-4348, USA \\ nancy.tomes@stonybrook.edu
}

\begin{abstract}
In an attempt to decolonize (the history of) global health, this paper aims to do three things. First, it claims that transposing the Enlightenment notion of a social contract in public health from a European to a global context has been an artificial move, and is in fact an artefact of colonial times. Secondly, it suggests a new kind of periodization for public and global health, using three consecutive logics which connect the motives of rulers and administrators to the perceived needs of their populations. Finally, it identifies several 'technologies of control' which are strategically used to come to an understanding of the practices (rather than the ideologies or blueprints) of global health.
\end{abstract}




\section{Keywords}

decolonization - global health - public health - social contract - racial contract health governance

\section{Introduction}

What does it mean to write about medicine and health in a post-pandemic era? That seems a question well worth posing in the initial issue of a new journal devoted to "all regions and covering all eras of the history of medicine and health" but based editorially in Europe. As we envision its future content, we are particularly interested in the opportunity to write history from a global perspective in the midst of efforts to 'decolonize' global health.

We have wrestled with this question since 2017, when we first began to think together about governance and accountability in post-1945 biomedicine and public health. Fortunately, we found colleagues willing to help us; in 2019, along with Noortje Jacobs, we created a network of scholars in the UK, the Netherlands, Canada, Brazil, South Africa, Ghana, Hong Kong, and Taiwan with a shared interest in exploring the different processes and practices associated with global health governance.

The most recent person to join our network is Seye Abimbola, Editor-inChief of BMJ Global Health, a physician and public health scholar. As the inaugural editor of that journal, he has thought deeply about questions of power, knowledge, global health, and the work of scholarly journals. As our new journal was launched, he has agreed to join us in discussing the history of global health and the ways that historians can help in the work of its decolonization. How do we avoid recapitulating the assumptions of the colonizers? How do we write history that helps address the challenges that a global pandemic, accelerating climate change, extreme income inequality, and entrenched prejudice pose to the already sharp divide between the global haves and have nots, variously termed LMICs and HIC s (Low- and Middle-Income Countries and High-Income Countries), Third and First World, Global South and Global North, Majority World and Minority World, developing and developed world, or simply rich versus poor? It has been an invigorating change of perspective akin to looking at the McArthur's 1979 'corrective map of the world' which shows the world south-side up (Fig. 1).

Now, after a year and a half of global pandemic, a more critical history of global health seems even more urgent. The COVID-19 pandemic has been a reality check and a wake-up call: while the world faces increasingly global challenges, it tends to respond to them in national - even nationalistic - ways. In 


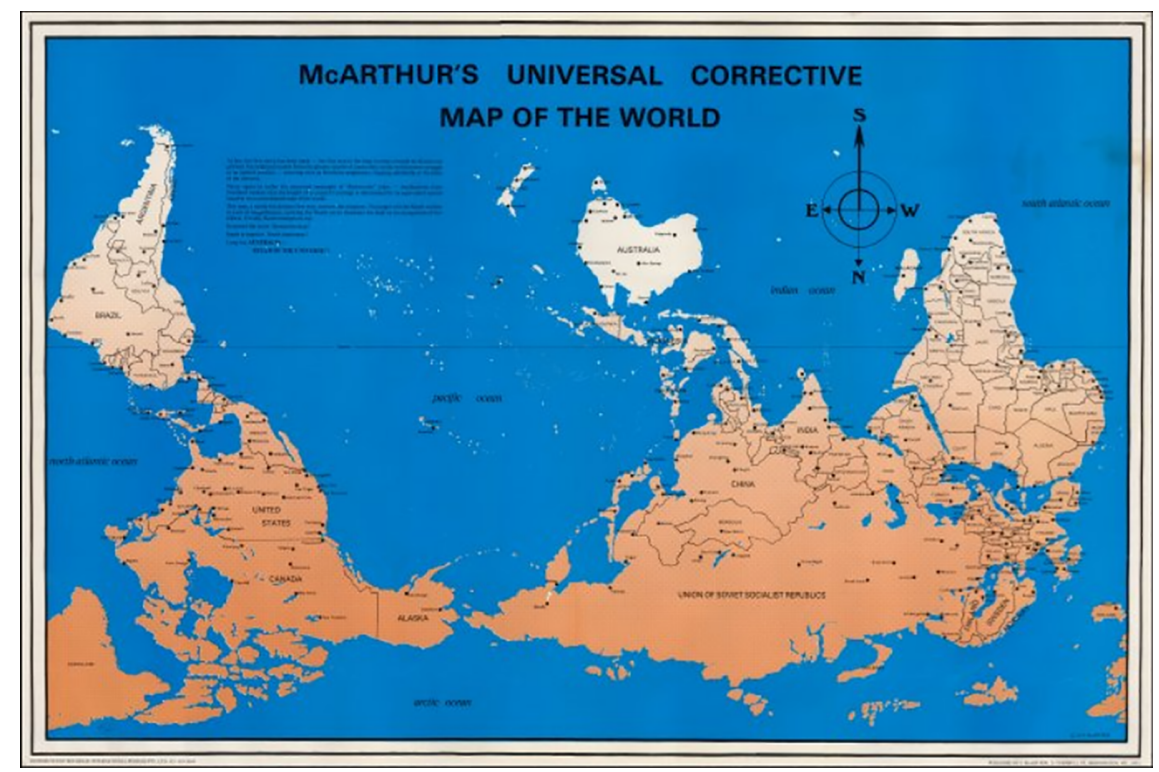

FIgURE 1 McArthur's 'Universal Corrective Map of the World' (1979)

response to the new virus every country around the globe opted for a different policy, ranging from strict lockdown through social distancing to downplaying or even ignoring the pandemic. In negotiating the terms of delivery of vaccines with pharmaceutical companies, governments put their own nation first. When vaccines became available, the conflict on the delivery of the AstraZeneca vaccine added yet another dimension to the Brexit crisis, exposing the lengths to which the European Union and the United Kingdom were prepared to go to serve their own interests, while ignoring those of the 'Global South' (Fig. 2). ${ }^{1}$

For all these reasons, we feel a new urgency to take up the work of our global network. As historians from the Global North with far more experience in gazing at more limited objects of study (nations, regions, medical specialties), we have had much to learn about thinking and writing from a global perspective. In his 2019 editorial "The Foreign Gaze: Authorship in Academic Global Health" in the BMJ Global Health, Abimbola articulates exactly the issues that have most troubled us: "There is a problem of gaze at the heart of academic global

1 For an indictment of the leadership of western liberal democracies by the Editor-in-Chief of The Lancet, see Richard Horton, The CovID-19 Catastrophe: What's Gone Wrong and How to Stop it Happening Again (Cambridge, 2020). See also Ellen 't Hoen and Pascale Boulet, "The European Commission says Covid-19 Vaccines Should be Global Public Goods, but do their Agreements with Pharma Reflect this?" Medicines Law \& Policy (2021), https://medicineslawandpolicy. $\mathrm{org} / 2 \mathrm{O} 21 / \mathrm{ol} /$ the-european-commission-says-covid-19-vaccines-should-be-global-publicgoods-but-do-their-agreements-with-pharma-reflect-this, last accessed 14 April 2021. 


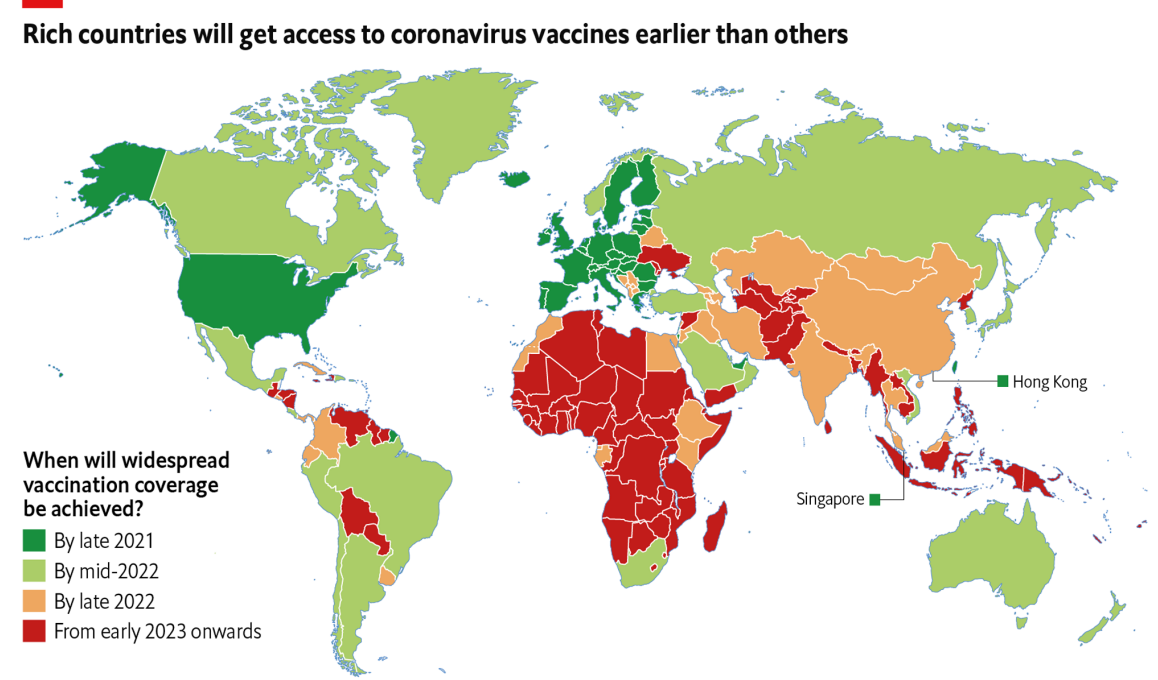

FIGURE 2 The (expected) Covid-19 vaccination coverage across the globe. ${ }^{2}$ Accurate as at January 22nd, 2021

SOURCE: THE ECONOMIST INTELLIGENCE UNIT

health", he writes in the first sentence. As he notes, "the entrenched power asymmetries in global health partnerships - between researchers in high-income countries (often the source of funds and agenda) and those in middle-income and especially low-income countries (where the research is often conducted)" are also reflected in scholarship. The 'foreign' gaze of researchers from HIC s more easily wins placement in the 'best' journals, while the local gaze of LMIC researchers ends up in so-called 'predatory' journals (i.e., journals that charge publication fees to authors, but with limited quality checks). Abimbola concludes that "in a globalizing world, our destinies are interlinked, and the origins of and solutions to delivery problems can be local or foreign. But in a world of power and information asymmetries, we see differently and understand differently." ${ }^{3}$

We agree wholeheartedly with Abimbola's call to attend to these asymmetries. What follows is the effort of two researchers (one Dutch, one American) to think more critically about the limits of our 'foreign gaze' as a precondition for more productive exchanges with public health leaders on the front lines of today's challenges. That challenge rightly begins with the

2 www.eiu.com/n/85-poor-countries-will-not-have-access-to-coronavirus-vaccines, last accessed 14 April 2021.

3 Seye Abimbola, "The Foreign Gaze: Authorship in Academic Global Health," BMJ Global Health, 4 (2019), doi:10.1136/bmjgh-2019-0o2068. 
necessity of rethinking the meaning of the terms national, international, and global, and how they intersect with our training - and limitations - as scholars.

We have to reckon first with the telling of public health as a 'European story', with the critical awareness that whatever goes for Europe does not go for other parts of the world; that there is no universal, unilinear, evolutionary path to modernity in the way in which communities organize themselves. As Dipesh Chakrabarty phrased it: "No country is a model to another country, though the discussion of modernity that thinks in terms of 'catching up' precisely posits such models". ${ }^{4}$ Critical thinking can never be universal but should always be related to place - and Chakrabarty argues that this goes for European thought as much as for Bengali thought. Global health is therefore not simply a matter of exporting 'Western' biomedical knowledge to the rest of the world, or for the rest of the world to finally catch up with 'the West', which supposedly sits on the highest rung of the evolutionary ladder. ${ }^{5}$ Provincializing Europe - both mentally and in real economic and scientific terms - is therefore a precondition for decolonizing global health which, in turn, is needed to allow the 'Global South' to come to into its own and to define its own priorities and agendas. ${ }^{6}$ In an attempt to create that much-needed intellectual space, we would like to take a closer look at the phases through which 'public health' went over time.

\section{$2 \quad$ Three Logics of Public Health}

Since the nineteenth century, the nation-state has been catering for the needs of the nation, at least in Europe and other 'Western' parts of the world. ${ }^{7}$ Over

4 Dipesh Chakrabarty, Provincializing Europe: Postcolonial Thought and Historical Difference (Princeton, NJ, 2008), xii; see also Rochona Majumdar, "Postcolonial History," in Debating New Approaches to History, ed. Marek Tamm and Peter Burke (London, 2019), 49-72.

5 One might even argue that the very notion of public health is a Western construction, based on the idea of a public space (in a Habermasian sense) of open rational discourse in a liberal nation state, which seems specific to the West. For that very reason, it cannot be simply exported to non-Western contexts; see, for example, Ruth Prince, "Situating Health and the Public in Africa," in Making and Unmaking Public Health in Africa: Ethnographic and Historical Perspectives, ed. Ruth Prince and Rebecca Marsland (Athens, OH, 2014), 1-51.

6 Richard Horton, "Offline: The Case Against Global Health," The Lancet (2014), https://doi. org/10.1016/So14o-6736(14)60797-2; Seye Abimbola, "The Information Problem in Global Health," BMJ Global Health, 1 (2016) doi:10.1136/bmjgh-2015-90ooo1; Ali Murad Büyüm et al., "Decolonizing Global Health: If Not Now, When?" BMJ Global Health (2020) doi:10.1136/ bmjgh-2020-003394. For a call to democratize knowledge production in global health, see Eugene Richardson, Epidemic Illusions: On the Coloniality of Global Public Health (Cambridge, MA, 2020).

$7 \quad$ We realize that dichotomies like the West and the rest, center and periphery, developed and developing, First and Third World, Global North and Global South are unhelpful and 
the course of the twentieth century, however, there has been an increasing awareness of human interconnectedness leading to global health threats. But how to organize global governance when a world-state is lacking? Global health can and has been defined by articulating what it is doing today. ${ }^{8}$ But it may be more instructive to look at the way in which its identity and mission have been defined historically. ${ }^{9}$ Historians can contribute to the larger project of decolonizing global health by putting these dynamics into a very long-range perspective. We propose to look at the governance of public health from the perspective of three consecutive logics, which we present as ideal types. They are the logic of the dynastic state, the logic of the nation-state, and the logic of global public-private partnerships. ${ }^{10}$

Although we recognize that there was 'public health' in the Middle Ages even before the infamous Black Death ${ }^{11}$ - our focus is on the 'post-Westphalian world'. The Peace of Westphalia in 1648 marked the end of more than a thousand years of politico-military struggle and strife after the collapse of the Western Roman Empire. Sovereign states came into being, putting an end to the 'feudal anarchy' of the Middle Ages. ${ }^{12}$ State power became depersonalized, meaning that the state was identified less with the personal authority of the ruler, and more with the offices and institutions under his supervision. The principle of territoriality linked the local to the national, while the body of the king represented the collective body of his subjects (as pictured on the frontispiece of Hobbes' Leviathan). Politics came to be associated with securing borders and maintaining the integrity and sovereignty of the state - in the interests of the monarch and his dynasty. Social and economic life was regulated to facilitate the extraction of human and monetary resources, i.e., healthy soldiers and tax-paying subjects. The cameralist and mercantilist needs of

even part of the problem. We have chosen to use these phrases for their heuristic value; see Arturo Escobar, Encountering Development: The Making and Unmaking of the Third World (Princeton, NJ, 1995/2012).

8 For the Global Health agenda of the wно, see www.who.int/about/vision/global_health_ agenda/en, last accessed 12 April 2021.

9 See also Randall Packard, A History of Global Health. Interventions into the Lives of Other Peoples (Baltimore, MD, 2016); Anne-Emanuelle Birn, Yogan Pillay and Timothy Holts, Textbook of Global Health (Oxford, 2017).

10 These logics are inspired by and build on Paul Unschuld, Ware Gesundheit: Das Ende der klassischen Medizin (Munich, 2014) and Eliot Freidson, Professionalism: The Third Logic (Cambridge, 2001).

11 See, for example, Guy Geltner, "The Path to Pistoia: Urban Hygiene Before the Black Death," Past and Present, 246 (2020), 3-33: https://doi.org/10.1093/pastj/gtzo28.

12 What follows is based in large part on Walter Opello and Stephen Rosow, The Nation-State and Global Order: A Historical Introduction to Contemporary Politics (London, 2004). 
the eighteenth-century monarchy were served by Johann Peter Frank. ${ }^{13}$ Even though the reforms he proposed in his multivolume System einer vollständigen medicinischen Polizey never materialized, they are the symbol of late eighteenth-century health policies, in which population policy was meant to serve economic policy: the wealth of any given state was measured by the size of its healthy population. Healthy subjects implied working and productive subjects, which in turn implied tax-paying subjects. On top of that, healthy men were fit to join the army, to protect and extend the territorial interests of the king and his dynasty. In the late eighteenth century, the advice and the services of Frank were in great demand: after having reformed the health-care system in Lombardy (then under Austrian rule), he was appointed director of the Vienna hospital, professor in Vilnius, staff member of the St. Petersburg clinic, and personal physician of the Russian tsar. Napoleon offered him the position of inspector general of the imperial health-care system (which Frank turned down for health reasons). In sum: while in Europe, a competitive system of sovereign dynastic states developed, these European states divided the world into spheres of influence. In the process, European colonialism and imperialism 'universalized' the concept and form of the state.

The French Revolution and the industrial revolution combined to produce a new logic: that of the liberal nation-state. While industrial capitalism created a new wealthy class (the bourgeoisie, demanding a place under the political sun), the Déclaration des droits de l'homme et du citoyen (solemnly proclaimed by the French National Assembly in 1789) formed the material expression of the idea of a social contract between the state and its citizens, which Enlightenment thinkers had been calling for. The revolutionaries believed that man could and should be created anew: l'homme régéneré. Henceforth, sovereignty was no longer considered to be embodied by the king (by divine right), but rather by the population of a territory. This was a truly revolutionary idea, creating "a new realm of individual freedom that weakened the absolutist state in favor of the individual, while paradoxically subjecting the individual to new forms of power, exercised by the state and others and aimed at molding and regulating public behavior ... Liberals set out self-consciously to reform the state so that it would support the private world of the individual in civil society, which they understood as the voluntary social interactions and organizations of rational

13 Markus Pieper, "Der Körper des Volkes und der gesunde Volkskörper: Johann Peter Franks 'System einer vollstaendigen medicinischen Polizey," Zeitschrift für Geschichtswissenschaft, 46 (1998), 101-119. 
individuals".14 Although the realization of the ideal of participatory citizenship proved to be a long and painful process, the nineteenth century produced a new conception of sovereignty and a new form of the state, extending suffrage and gradually transforming all subjects into citizens. But first, the problems of poverty, illiteracy and disease - potential threats to the new bourgeois order and obstacles to full participatory citizenship - needed to be addressed.

The needs of the nineteenth-century industrial liberal nation-state were served by Edwin Chadwick. ${ }^{15} \mathrm{~A}$ former assistant of the utilitarian philosopher Jeremy Bentham, he helped draft the new Poor Law (1834) and the Ten Hours Act (1847), but he is mainly known for his Report on the Sanitary Condition of the Labouring Population of Great Britain (1842), which would ultimately lead to the Public Health Act (1848). Fully convinced that poverty and disease were two sides of the same coin, his approach was statistical and bureaucratic. Statistical research was to trace patterns in the etiology of disease and supply the data on which the state could act. As had been the case with the proposals of Frank, Chadwick's sanitary ideas (on an arteriovenous system, including clean drinking-water and a sewage system, and on the exchange of dung for food in the relationship between city and countryside) materialized only very slowly, mainly because of the large costs involved. But the point here is that Chadwick's sanitarianism fitted perfectly the political needs of the new ruling class. Early nineteenth-century public health in industrialized states tried to do two things: first, to promote the health of the working class (as dynastic public health had done) and secondly, to counter the revolutionary threat in industrialized society. In this respect, England resembled Germany, that other leading industrializing nation. ${ }^{16}$ Despite the fact that policies in Germany were imposed by the state while in England they tended to be based on voluntarism and local initiative, both countries needed to find answers to the social consequences of industrial capitalism. After he had unified Germany in 1871, Otto von Bismarck engaged in creating a nation and building the economy. Through social legislation (selectively focused on wage laborers rather than on the whole population), he succeeded in suppressing the socialist movement and winning the loyalty of workers to the new nation. Over time, more and more people acquired political participation (first workers, then women), and

\footnotetext{
14 Opello and Rosow, Nation-State and Global Order, 101 and 102.

15 Christopher Hamlin, Public Health and Social Justice in the Age of Chadwick: Britain, 180o1854 (Cambridge, 1998).

16 Ernest P. Hennock, "Vaccination Policy Against Smallpox, 1835-1914: a Comparison of England with Prussia and Imperial Germany," Social History of Medicine, 11 (1998), 49-71; idem, The Origin of the Welfare State in England and Germany, 1850-1914: Social Policies Compared (Cambridge, 2007).
} 
universal suffrage led to profound changes in social legislation, also including health care policies. Despite differences between countries, one might argue that the social contract - in which rights and duties were negotiated between all free citizens - had become a reality in the modern European nation-state.

The logic of global public-private partnerships developed in the late twentieth century, as a result of the decolonization process after World War II, the introduction of neoliberal policies in the 1980s, and the end of the Cold War in 1989. At the beginning of the twentieth century, the global order was one of sovereign territorial states within Europe and European colonial empires elsewhere in the world. ${ }^{17}$ Over the course of four centuries, European states had carved the infinite space of the world into empires, jurisdictions, and spheres of influence over which they claimed sovereignty. Europeans expanded their sovereignty by extending their principles and practices of administration, which were based on their conception of colonies as their private property. Taking this idea to its logical extreme, European imperial powers divided Africa among themselves at a conference in Berlin in $1885 .{ }^{18}$ Opello and Rosow observe: "Through imperialism European states transferred the idea of the state to non-European parts of the world, which laid the foundation of the present global system of sovereign territorial states... Thus, non-European people acquired the state as an institutional artefact of colonialism". ${ }^{19}$ This may be the tragedy of the 'Global South': given the fact that nations are not natural entities but rather imagined and historically constructed (in this case: by the colonial state), and taking into account that contemporary nation-states are an artefact of European conquest and colonialism, the daunting challenge of the newly independent states is to find their own identity and define their own priorities and agendas in the face of stiff competition from the 'Global North'. ${ }^{20}$

In the 1950s and 196os, a decolonization process was set in motion, leading to new global realities. The idea of the self-determination of peoples became a principle of the global system of states. Formerly colonized states could henceforth rule themselves. After having gained independence, the former colonies decided to either emulate and imitate the former colonizing country on the road to 'modernity', or diametrically oppose it and go their own way.

17 Opello and Rosow, Nation-State and Global Order, chapter 8; Birn et al., Textbook of Global Health, 169-172.

18 Steven Press, Rogue Empires: Contracts and Conmen in Europe's Scramble for Africa (Cambridge, MA, 2017).

19 Opello and Rosow, Nation-State and Global Order, 191.

20 Benedict Anderson, Imagined Communities. Reflections on the Origin and Spread of Nationalism, revised edition (London, 1983/2006); Eric Hobsbawm and Terence Ranger, eds., The Invention of Tradition (Cambridge, 1983). 
But whatever they chose, the road ahead was long and bumpy: first, because the colonial legacy imposed limits to their sovereignty, and second, because powerful states and institutions in the 'Global North' tried to align them with the interests of the world economy. The ultimate irony was that when former colonies gained independence, the very concept of the nation-state was being challenged by the globalization of the capitalist economy. After World War II, the United States had created a globally managed 'free-trade' system, which benefitted large trans- and multinational corporations. This undermined the position of the state, because it lost its connection to a specific territory and a distinct people. Embracing the neoliberal agenda in the 199os gave the deathblow to state power. It implied the delegation of state power to international organizations and the world market, and its diffusion through privatization. ${ }^{21}$

The role of the United Nations reflected these dynamics. Mark Mazower has debunked the popular myth that the UN miraculously rose from the ashes of World War II as the guardian of a new and peaceful global order. ${ }^{22}$ After the war, the world was divided into three 'worlds' (First, Second and Third). Like its predecessor, the UN was really protecting the interests of empire, Mazower argues. Just like the League of Nations had protected the interests of the British Empire, the UN was now protecting those of the American Empire. Like the League, the UN was said to be a cooperative grouping of independent sovereign states. But the states gathered together in the General Assembly could do very little when faced with a veto of the Security Council. Whatever the rhetoric, the UN was designed for interstate cooperation and stability in a world of empires and great powers.

For all its limitations, the UN - and the international order it reflected affected 'public health' in important ways, both nationally and globally. In 1948, the Universal Declaration of Human Rights was adopted by the United Nations General Assembly. Although not legally binding, it is generally considered to be a foundational text in the history of human and civil rights, proclaiming their universal character as inalienable and universal. Article 25 stipulated: "Everyone has the right to a standard of living adequate for the health and well-being of himself and of his family, including food, clothing, housing and medical care and necessary social services, and the right to security in the event of unemployment, sickness, disability, widowhood, old age

21 Opello and Rosow, Nation-State and Global Order, chapter 12. As Prince writes: "While Michel Foucault located biopolitics in the relations between the state and its populations, contemporary interventions into 'life itself' are driven by the market, specifically, the pharmaceutical industry and its pursuit of "biocapital": Prince, "Situating Health," 7.

22 Mark Mazower, No Enchanted Place: The End of Empire and the Ideological Origins of the United Nations (Princeton, NJ, 20o9). 
or other lack of livelihood in circumstances beyond his control". It sounded like a new social contract. This time, however, it was not agreed between the free citizens of a territorial nation-state, but presented by the United Nations to the world. Nothing much happened in concrete terms, until a new concept was coined in the late 1970s and 1980s: Primary Health Care. ${ }^{23}$ Under the leadership of Halfdan Mahler - the Danish physician who was director-general of the wHo from 1973 to 1988 and a great believer in social justice - the report Alternative Approaches to Meeting Basic Health Needs in Developing Countries (1975) was followed by the international conference on primary health care in Alma Ata (1978). It was recognized that in the new international order, modernization need not to imply replicating the US model of development. The Declaration of Alma Ata advocated 'appropriate' rather than 'disease-oriented' technology, denounced top-down health campaigns, and suggested an intersectoral approach (integrating education, nutrition, housing, water supply and sanitation) as the way forward to promote health. In 1981, the World Health Assembly proclaimed its Global Strategy for Health for All.

How did that play out in the post-Cold War era? In 1988, the Japanese physician Hiroshi Nakajima succeeded Mahler as director-general. Under Nakajima, the WHO remedicalized, cut down on primary health care, and overall lost much of its worldwide credibility. The 'Nordic socialism' of Mahler was superseded by neoliberal policies, while public-private partnerships took over the leadership role of the wHo. Henceforth, only lip service was paid to the structural determinants of health, which had been prominent at the Alma Ata conference. It received very little serious attention or funding. ${ }^{24}$ In 1989 , the Iron Curtain came down, which effectively meant the end of the Cold War. Two years later, the Soviet Union collapsed, making the United States a hyperpower. Francis Fukuyama - who was deputy director of the planning-staff of the US State Department - self-consciously claimed the victory of economic and political liberalism. He suggested that there was now global consensus about the value of neoliberalism and that history - as manifested in ideological conflict - had come to an end: "The triumph of the West, of the Western idea, is evident first of all in the total exhaustion of viable systematic alternatives to Western liberalism". ${ }^{25}$ Western liberal democracy had proven to be

23 Marcos Cueto, Theodore M. Brown and Elizabeth Fee, The World Health Organization (Cambridge, 2019), chapter 7; Packard, History of Global Health, chapter 12 and 13.

24 Packard, History of Global Health, 270 and chapter 16.

25 Francis Fukuyama, "The End of History?" The National Interest, 16 (1989), 3-18 on 3. For a compelling analysis of what one might call 'the end of American neoliberalism', see Ivan Krastev and Stephen Holmes, The Light that Failed: A Reckoning (Harmondsworth, 2019), which argues that the Age of Imitation - in which Eastern European and other countries 
"the final form of human government". However, Fukuyama made it perfectly clear that this only went for 'Western' countries in the 'Global North', who had now shaken off the chains of history, transcended narrow-minded nationalism and created a de-ideologized world: "Clearly, the vast bulk of the Third World remains very much mired in history, and will be a terrain of conflict for many years to come". Fukuyama chose to focus on "the larger and more developed states of the world who after all account for the greater part of world politics". ${ }^{26}$ The part of the world that had reached the end of history was to focus on the economy rather than on politics, and he predicted the marketization of international relations, in which there would only be economic calculation and the satisfaction of sophisticated consumer demands.

It quickly became clear what this entailed for the 'Global South'. Pressured by the United States and other industrialized countries, the budget of the WHO was frozen. At the same time, the role of the World Bank in the international health arena was growing. ${ }^{27}$ By 1997, the Bank had become the biggest public health funder in the world. Whereas in the past, the Bank had considered health expenditures as unproductive and as drains on public finances, it came to view them as potentially productive investments. Its 1993 report Investing in Health can be viewed as the Bank's assertion of a leadership role in international health. Although 'developing countries' since 1950 had witnessed an impressive increase in life expectancy (from 40 to 6o), the report noted many challenges as well. There was still misallocation of funds, inequity in access to basic health services, inefficiency and - partly as a result - exploding costs. To meet these challenges, the report called for cost-effectiveness and for competition between public and private parties in the delivery of health services. In his Foreword, Lewis Preston, president of the World Bank, wrote: "governments need to promote greater diversity and competition in the financing and delivery of health services". ${ }^{28}$ The report as a whole argued that a healthy population was a precondition for economic growth. This so-called 'Washington consensus' was fully in line with the two preceding logics (of the dynastic state and of the nation-state). This time however, the logic was far more complex,

emulated the Western model of liberal democracy - started in 1989, and ended somewhere between 2008 (the global financial crisis) and 2016 (the year in which Donald Trump was elected President of the USA). Today, history continues with the world-changing competition between America and China.

26 Ibid., 15 .

27 Cueto et al., The World Health Organization, chapter 9 and 10; Packard, History of Global Health, chapter 14.

28 World Bank, World Development Report 1993: Investing in Health (Oxford, 1993), iii. 
because it was no longer connected to a territory or a nation - but rather to the globe.

By the end of the twentieth century, the wно was criticized as being politicized, underfunded and overcommitted. The new director-general, the Norwegian physician and former Prime Minister of Norway, Gro Brundtland, was firmly committed to restoring the wHO's standing in the world. Because national health systems had failed, she brokered new alliances between many different stakeholders, also known as public-private partnerships. It led to alliances between UNICEF, the World Bank, the Rockefeller Foundation, the Bill and Melinda Gates Foundation, vaccine manufacturers, medical research institutes, and governments of industrializing and developing countries. Ambitious eradication campaigns were set up against malaria, tuberculosis, AIDS and lung cancer, but it often remained unclear which ideals, interests or motives these hybrid partnerships were really serving: countering poverty and disease, promoting national economic development, or supporting personal enrichment. The outbreak of SARS in 2002-3 has been called "the first post-Westphalian pathogen", meaning that it was the first pathogen to emerge into a governance structure that substantially differed from earlier ones, characterized by collaborating sovereign nation-states. ${ }^{29}$ Although SARS was successfully contained, the new governance structure of global health could not prevent Ebola, MERS or Zika - or indeed COVID-19.

Public-private partnerships are criticized for their lack of transparency and accountability: while people across the globe are subject to the discipline imposed by the International Monetary Fund, the World Bank, multinational corporations, philanthro-capitalists and the global financial markets, members of PPP's are not democratically elected - nor are they accountable to some sort of constituency. In the global system of deterritorialized transnational organizations, decision-making processes have increasingly become nontransparent..$^{30}$ This leads to questions like: "What or who must be valued in order for knowledge to count as global health science, and what or who remains subjacent or unaddressed? How can donors and governments be held accountable

29 David Fidler, SARS, Governance and the Globalization of Disease (Houndmills, 2004).

30 Some have even argued that the system is broken and has to change: "What is at stake is whether the reform of our common life is led by governments elected by and accountable to the people, or rather by wealthy elites claiming to know our best interests" - Anand Giridharadas, Winners Take All: The Elite Charade of Changing the World (New York, 2018), 7 and 10. 
in the long run, especially in volatile times? How can human rights and equity concerns be integrated into global health research and policy?"31

Recently, Robtel Pailey decided to address the elephant in the room with regard to development: racism. ${ }^{32}$ She writes: "It puzzles me how we talk and theorize about development as if its historical antecedents - slavery, colonialism, imperialism - and its contemporary manifestations - globalization, neoliberalism - have not produced racialized 'phenotypic others'... How can we truly 'open up development' without openly talking about how it suffers from a 'white gaze' problem?... Western whiteness remains a signifier of expertise, whether real or perceived... We Africans have thoroughly internalized the 'white gaze' of development". In this context, she is referring to Charles Mills, who wrote: "the peculiar contract to which I am referring, though based on the social contract tradition that has been central to Western political theory, is not a contract between everybody ('we the people'), but between just the people who count, the people who really are people ('we the white people'). So, it is a Racial Contract". ${ }^{33}$ While the European social contract had been based on the theorizing of Hobbes, Locke and Rousseau, and on the voluntary consent of free citizens, the global racial contract was enforced through imperial interests and ideologies, and on violence. In other words: the heritage of imperialism still lingers on in global health.

We end back where we begin: with the growing awareness of the interconnectedness of mankind, also in terms of health and disease. A need was felt to address (re)emerging diseases by thinking and acting globally. As Richard Horton, editor-in-chief of The Lancet, tweeted in 2012: "Global health is an attitude. It is a way of looking at the world. It is about the universal nature of our human predicament. It is a statement about our commitment to health as a fundamental quality of liberty and equity". ${ }^{34}$ Although this is a very sympathetic vision and mission, there are many obstacles along the way. How do we realize global health, when we know that low- and middle-income countries account for 84 percent of the world's population, 9o percent of the world's

$31 \quad$ João Biehl and Adriana Petryna, "Critical Global Health" in When People Come First: Critical Studies in Global Health, ed. Biehl and Petryna (Princeton, NJ, 2013), 1-20, on 15.

Robtel Neajai Pailey, "De-Centring the "White Gaze" of Development," Development and Change, 51 (2019), 729-745; see also Ann Laura Stoler, Carnal Knowledge and Imperial Power: Race and the Intimate in Colonial Rule (Berkeley, CA, 2002).

33 Charles Mills, The Racial Contract (Ithaca, NY, 1997), 3; see also Laurie Garrett, Betrayal of Trust: The Collapse of Global Public Health (New York, 200o).

34 Richard Horton, https://twitter.com/richardhortoni/status/163641986o35888129?lang=en. In a similar vein is the call by Mbih Tosam et al., "Global Health Inequalities and the Need for Solidarity: a view from the Global South," Developing World Bioethics, 18 (2018), doi: 10.1111/ dewb.12182. 
disease burden, 24 percent of the world's GDP, and only 13 percent of global health expenditure? ${ }^{35}$ How do we account for the enormous differences within and between health care systems, and governance structures falling short of rectifying the resulting inequity between people? How do we reckon with the gross lack of unbiased evidence to guide public policy? By the time we finally recognize that in order to achieve equity and health in the 'Global South', a thriving discipline has come into existence in the 'Global North. ${ }^{36}$ Taking all of this into account, we can only agree with Paul Farmer when he writes: "Global health, while a marked improvement on its forebear 'international health', remains a collection of problems rather than a discipline".37

\section{Technologies of Control, or Tools of Health Governance}

Much good work is being done today on the history of global health. In our Global Health network, our goal is not to duplicate what is being done, but rather to focus on a specific strength that we believe we can offer: the ability to critically assess the processes and procedures used in global health governance. By that we mean the creation, use, and modification of specific technologies of control or tools of health governance. These might include professional regulations, ethics committees, standardized disease nomenclatures, comparative metrics of infant mortality, prospective payment systems or 'patient-centered' medicine. This way, we hope to make the logic and dynamics of the global public-private partnerships visible. ${ }^{38}$ Crudely put, the objects of our study are the 'things' that are used to govern: the practices and evidentiary bases on which they rely. What we want to learn more about are the origins, travels, and impacts of specific techniques of health governance. We are interested in how unresolved conflicts and unexamined assumptions embedded in those techniques have helped to produce a sense of discontent and failure among multiple stakeholders in multiple sites, from the US to Ghana. Put differently, we want

35 Anne Mills, "Health Systems in Low- and Middle-Income Countries," in The Oxford Handbook of Health Economics, ed. Sherry Glied and Peter Smith (Oxford, 2011), 30-57.

36 Anita Svadzian, Nathaly Aguilera Vasquez, Seye Abimbola and Madhukar Pai, "Global Health Degrees: At What Cost?” BMJ Global Health, 5 (2020), doi:10.1136/bmjgh-2020-003310.

37 Paul Farmer, "Preface" to Reimagining Global Health:An Introduction, ed. Paul Farmer, Arthur Kleinman, Jim Kim and Matthew Basilico (Berkeley, CA, 2013), xiii.

38 The two paradigms in global health are embodied by Médecins sans Frontières (apolitical, biomedical, focused on rapid response) and Partners in Health (considers health care as a human right, focused on social determinants of health, long-term commitment); see Packard, History of Global Health, 332-341. 
to historicize and critically examine the genesis and global travel of supposedly 'scientific' and 'universally applicable' tools of health governance. As part of larger governance regimes, these processes and practices aim at encouraging or compelling actors at every level - from wHO and Ministry of Health officials to patients in doctors' offices or refugee clinics - to think and behave in certain ways towards certain ends. We are trying to connect different processes across domains that are rarely seen in relation to one another, so as to disclose possible synergies or conflicts among measures intended to promote purportedly 'higher' levels of ethical, scientific, fiscal, and social accountability.

In so doing, we want to explore the role of health in the evolution of late-twentieth century neoliberal regimes, as well as highlight the criticisms of, and alternatives to, its precepts that have emerged in many places. By historicizing these tools and techniques, as well as the responses to them, we want to denaturalize or decolonize them; that is, to disrupt their sense of inevitability and basis in the 'universal truths' of science and social science. We want to foreground the unresolved problems and unexamined assumptions embedded in them, and the consequences (intended and unintended) that flow from them as they travel. Tools and procedures originate in one place and set of circumstances; they are taken up and used in other places and circumstances, with the imprimatur of being universally useful and 'evidence based'. They are portrayed as tools aligned with (social)science, expert knowledge, and 'trust in numbers'. They are presented by powerful stakeholders as the best means towards 'progress'. They are resisted by other stakeholders who may hold less power but are far more grounded in local realities and institutions. They may be 'vernacularized' and turned to different purposes by those stakeholders.

By tracking these movements and debates, our purpose is to challenge one-sided narratives about 'progress' in health governance using critical perspectives from science and technology studies. Through this work, we want to bring a more informed, sophisticated historical perspective to the post-World War II evolution of global health governance. The proponents of specific tools and procedures are usually their first historians; in promoting their innovations, they provide partial and misleading accounts of their genesis. As historians, we offer a more informed perspective on the nature of change over time. We are adopting a longue durée perspective on the nature of health governance that identifies continuity as well as change from the nineteenth century to the early twenty-first century. To this end, we want to track those tools and procedures (i.e., professional regulations, ethics committees, standardized disease nomenclatures, comparative metrics of infant mortality, prospective payment systems, or 'patient-centered' medicine) in multiple ways: 
(a) As the foundation of new kinds of systems thinking that have undergirded health governance since World War II, at both the national and international level, including the global health governance approaches taken by the wHO and the foundations of philanthro-capitalists.

(b) As products and tools of major shifts in global politics: from colonial to post- and neocolonial times, before and after the Cold War, before and after the fall of the Berlin Wall in 1989, before and after the reconfiguration of major powers to include the majority world leaders such as the PRC and India.

(c) As 'technics that travel': i.e., practices that were developed in response to a specific country's challenges and then got taken up by other countries on the back of the globalization of biomedicine and health care post-World War II.

(d) As a 'knowledge infrastructure': how Western systems of knowledge production, use, and circulation emerged to legitimize biases and myths about other systems of knowledge production, use, and circulation in global health.

(e) As the focal point for discontent and a sense of failure across a wide spectrum of health actors, including physicians and patients in both minority and majority nations.

(f) At a material level: how did methods of compiling and analyzing information, demanding accountability, and promoting policy objectives change as they evolved from paper-based systems to machine-assisted, digitized systems? And what effects has this had on health system governance in the arenas of international and global health?

Very often, 'the global' is presented as a neutral, post-national framework with a free flow of capital, while Western biomedicine is presented as a universal body of knowledge in need of global implementation. In line with this view, 'globalization' is evaluated as a positive trend with equity and health just around the corner. In order to speed up the process, there have been calls for stronger leadership in global health, suggesting that the UN, the wHO and the World Bank should step up their efforts. ${ }^{39}$ In response to this, we would like to suggest that globalization is an ideology and an economic phenomenon in a post-national world, that Western biomedicine cannot be simply implemented in any given context, and that there are huge asymmetries in knowledge, power and resources standing in the way of achieving the lofty ideal of

39 Marco Schäferhoff, Sabine Campe, and Christopher Kaan, Rethinking the Global Health System (London, 2015). 
global health. As Svadzian et al. note: "The traditional mindset in global health that expertise flows from North to South, is reflected in research, training, consultancy and technical assistance. This colonial model is ripe for disruption". ${ }^{40}$ For this to happen, it is essential to realize that there are no universals in public health, that Western biomedical notions cannot not be simply imposed on non-Western contexts, and that there are therefore limits to Western expert opinion. ${ }^{41}$ The Governance in Global Health network is keen to analyze the development and dynamics in global health. In doing so, it hopes to contribute to decolonizing global health.

\section{Acknowledgements}

We would like to thank Seye Abimbola for his comments on an earlier version of this article. We would also like to thank all the members of the Global Health Governance and Accountability Network who have contributed so much to the views expressed in this article: Anne-Emanuelle Birn, Simplice Ayangma Bonoho, Marcos Cueto, Emily Harrison, Noortje Jacobs, Wen-Hua Kuo, Projit Bihari Mukharji, John Onokwai, David Reubi, Dora Vargha, George Weisz, Duncan Wilson, and Harry Yi-Jui Wu.

$40 \quad$ Svadzian et al., "Global Health Degrees," 7.

41 Cf. the pertinent comments of Seye Abimbola on the 'information paradox' ("On the Meaning of Global Health and the Role of Global Health Journals," BMJ Global Health, 10 (2018), doi: 10.1093/inthealth/ihyo1o), and his call for subsidiarity in a global order in which knowledge will lead to equity ("The Uses of Knowledge in Global Health," BMJ Global Health, 6 (2021), doi:10.1136/bmjgh-2021-005802). On this issue, see also Miranda Fricker, Epistemic Injustice: Power and Ethics of Knowing (Oxford, 2009). 